Ching-Yue Yang MD, ${ }^{*}$ Chih-Shung Wong MD PhD,* Jang-Yang Chang MD, $\uparrow$ Shung-Tai Ho MD*

\section{Intrathecal ketamine reduces morphine requirements in patients with terminal cancer pain}

$\left(0.17 \pm 0.02 \mathrm{mg} \cdot\right.$ day $\left.^{-1}\right)(P<0.05)$. The average pain scales were $7.95 \pm 0.25$ before intrathecal drug administration. Pain scales were decreased to $2.2 \pm 0.17(P<0.05)$ in phase $M$ and $1.95 \pm 0.20(P<0.05)$ in phase $M+K$ after the effective dose of morphine had been reached. No serious side effects were observed in this study.

Conclusion: The present study demonstrates that ketamine enhances the analgesic effect of morphine, thus reducing the dose of intrathecal morphine.

Objectif: La kétamine a été administrée par l'approche épidurale et sous-arachnoïdienne pour contrôler la douleur per- $e t$ postopératoire. Des études chez l'animal ont révélé que l'analgésie était potentialisée lorsque la kétamine était associée à la morphine. Nous avons vérifié si la ketamine sousarachnoïdienne potentialisait la morphine sous-arachnoïdienne dans le traitement de la douleur du cancer.

Méthodes: Cette étude en double aveugle entrecroisée visait à évaluer l'effet de la kétamine sur la morphine sous-arachnoidienne administrée à des cancéreux en phase terminale. Un protocole en deux phases a été élaboré pour la voie sousarachnoidienne: phase $M$, morphine seule deux fois par jour; phase $M+K$, association de kétamine $(1,0 \mathrm{mg})$ avec morphine deux fois par jour. La dose de morphine a été augmentée jusqu'à ce qu'un niveau acceptable de soulagement soit atteint, défini sur une échelle numérique $(0-10) \leq 3$, et la dose de sauvetage de morphine a été inférieure à $5 \mathrm{mg}$ après chaque administration sous-arachnoïdienne pour deux jours. La dose de morphine était définie comme la dose efficace.

Résultats: En phase $M$, la dose efficace de morphine sousarachnoïdienne de $0,38 \pm 0,04 \mathrm{mg} \cdot \mathrm{j}^{-1}$ a été plus élevée qu'en phase $M+K\left(0,17 \pm 0,02 \mathrm{mg} \cdot j^{-1}(P<0,05)\right.$. Les échelles d'évaluation de la douleur moyenne étaient de 7,95 $\pm 0,25$ avant l'injection sous-arachnoïdienne. Ces échelles ont baissé à 2,2 $\pm 0,17(P<0,05)$ en phase $M$ et à 1,95 $\pm 0,20(P<0,05)$ en phase $M+K$ une fois la dose efficace de morphine atteinte. Il n'y a pas eu d'effets secondaires sérieux.

Conclusion: La présente étude montre que la kétamine aug mente l'effet analgésique de la morphine et réduit ainsi la dose de morphine sous-arachnoïdienne. 
TABLE I. Profile of patients

\begin{tabular}{|c|c|c|c|c|c|c|}
\hline No & Sex & Age & Primary site & Location of pain & $\begin{array}{l}\text { Duration } \\
\text { (month) }\end{array}$ & Opioid usage \\
\hline 1 & $\mathbf{M}$ & 61 & Stomach & Upper abdomen & 30 & im morphine \\
\hline 2 & $\mathrm{~F}$ & 36 & Cervix & Lower abdomen & 6 & im meperidine \\
\hline 3 & $\mathrm{~F}$ & 57 & Liver & Upper abdomen & 3 & po morphine \\
\hline 4 & $\mathrm{~F}$ & 43 & Liver & Upper abdomen & 9 & im meperidine \\
\hline 5 & $\mathbf{M}$ & 65 & Lung & Right arm and shoulder & 10 & iv morphine \\
\hline 6 & $\mathrm{M}$ & 69 & Lung & Lower back & 12 & po morphine \\
\hline 7 & $\mathrm{M}$ & 67 & Liver & Upper abdomen & 3 & im meperidine \\
\hline 8 & $\mathbf{F}$ & 46 & Stomach & Abdomen & 10 & iv morphine \\
\hline 9 & $\mathrm{M}$ & 55 & Stomach & Upper abdomen & 8 & im morphine \\
\hline 10 & $\mathbf{M}$ & 62 & Colon & Lower abdomen & 24 & $\begin{array}{l}\text { po codeine } \\
\text { im morphine }\end{array}$ \\
\hline 11 & $\mathrm{M}$ & 22 & Liver & Upper abdomen & 3 & im meperidine \\
\hline 12 & M & 59 & Lung & Right chest & 36 & po codeine \\
\hline 13 & $\mathbf{M}$ & 24 & Lung & Lower back & 7 & im morphine \\
\hline 14 & $\mathbf{F}$ & 57 & Cervix & Lower abdomen & 36 & im morphine \\
\hline 15 & $F$ & 58 & Colon & Lower abdomen and back & 36 & po morphine \\
\hline 16 & $\mathbf{F}$ & 38 & Stomach & Abdomen & 5 & im meperidine \\
\hline 17 & $\mathbf{F}$ & 52 & Pancreas & Upper abdomen & 6 & iv morphine \\
\hline 18 & $\mathbf{M}$ & 69 & Colon & Back & 18 & iv morphine \\
\hline 19 & $\mathbf{F}$ & 68 & Pancreas & Upper abdomen & 6 & im morphine \\
\hline 20 & $\mathbf{F}$ & 67 & Stomach & Upper abdomen & 7 & po morphine \\
\hline
\end{tabular}

Spinal ketamine has been used for postoperative pain control and produces spinal anaesthesia after intrathecal administration. ${ }^{1-3}$ Animal experiments showed that intrathecal administration of ketamine, with benzethonium chloride as preservative, was not associated with macroscopic abnormalities in the spinal cord. ${ }^{4,5}$

Intrathecal morphine has been used for cancer pain control, especially in patients who experience inadequate analgesia, intolerable side effects or who have an excellent response to intrathecal administration. ${ }^{6}$ However, it is associated with many side effects, such as pruritus, nausea, vomiting, urinary retention, respiratory depression and tolerance. ${ }^{7}$

Animal studies have shown potentiation of analgesia by a combination of ketamine and morphine, ${ }^{8,9}$ suggesting that ketamine involves opioid interaction. This study, in patients with terminal cancer pain, was designed to determine whether intrathecal ketamine potentiated in-trathecal morphine, and decreased its side effects.

\section{Methods}

Twenty hospitalized patients, 10 men and 10 women, aged 22 to 69 yr were selected from patients referred to the Tri-service General Hospital, National Defense Medical Center from October 1993 to July 1995. The primary diagnosis included metastatic cervical cancer; lung cancer; hepatoma; colon cancer; pancreatic cancer and stomach cancer (Table I). The study was approved by the Ethics Committee of Health of the hospital, its nature and purpose were described and written informed consent was obtained from each participant.

All patients used opioid analgesics for pain control before the study and the pain was of variable severity with pre-study analgesics. They all agreed to be implanted with an intrathecal Port-A-Cath (Pharmacia Deltec Inc. St Paul, MN 55112 U.S.A.), a catheter for intrathecal drug injection, ${ }^{10}$ to control cancer pain. After implantation, the study was divided into two phases. In phase $\mathbf{M}$ (morphine), intrathecal morphine was given alone twice daily; and in phase $M+K$ (morphine plus ketamine), ketamine $1.0 \mathrm{mg}$ with benzethonium chloride as preservative was combined with morphine intrathecally twice daily. Intrathecal treatment began after random assignment to either phase $M$ or phase $M+K$, with concomitant medications such as tranquilizers, bronchodilators or laxatives continued as previously. A double dummy technique was used, so that the patient, investigator and nurse were unaware of the dose of morphine and ketamine.

The intrathecal dose of morphine started at $0.05 \mathrm{mg}$ and was increased in daily increments not exceeding the previous daily dose until acceptable analgesia was obtained (see below). The injected drug was flushed with $2 \mathrm{ml}$ normal saline to ensure entrance into the intrathecal space (volume of reservoir and catheter of Port-A-Cath $<0.7 \mathrm{ml}$ ).

A rescue dose of $5 \mathrm{mg}$ morphine $i m$ was administered as needed for pain. Doses of intrathecal morphine were increased until acceptable analgesia or the effective dose 
was achieved, i.e., rescue doses of morphine of $\leq 5 \mathrm{mg}$ after each intrathecal administration and pain scale was $\leq 3$. After achieving and maintaining acceptable analgesia for $48 \mathrm{hr}$ in the first phase of the study, patients were ranidomly crossed over to the alternate phase, again starting with intrathecal morphine titration. There was no washout period between two phases.

Self-assessment of pain, life interference and sleep deprivation were evaluated on a $0-10$ numeric rating scale. Patients were asked to rate their pain from 0 (no pain at all) to 10 (the worst pain imaginable). Pain frequency was evaluated on a four point verbal ordinal scale (0, "none to rare"; 1 , "occasional"; 2 , "frequent"; or 3, "constant"). The intrathecal morphine dose, im rescue morphine dose and intrathecal morphine titrated frequency were also recorded. Side effects including pruritus, constipation, urinary retention, difficulty of urination, nausea, vomiting, hallucination and respiratory depression were evaluated by "yes" or "no". Respiratory depression was defined by a respiratory rate $<10$ per $\mathrm{min}$. All evaluations were performed twice daily at the same time.

For statistical analysis, group differences in the effective dose of intrathecal morphine, total titrated dose of intrathecal morphine, total dose of $i m$ rescue morphine and total number of intrathecal injections between phase $M$ and phase $M+K$ were analyzed by paired $t$ test. The difference in pain intensity, pain frequency, life interference and sleep deprivation were tested by repeated-measures ANOVA. Differences between groups were tested by Dunnett's test. The differences in the frequency of side effects between phase $M$ and phase $M+K$ were analyzed by repeated-measures chi-square test. Statistical significance was assessed when $P<0.05$.

\section{Results}

On the last day of phase $\mathrm{M}$, patients required intrathecal morphine $0.38 \pm 0.04 \mathrm{mg} \cdot$ day $^{-1}$ to obtain acceptable pain relief. On the last day of phase $M+K$, this had decreased to $0.17 \pm 0.02 \mathrm{mg} \cdot \mathrm{day}^{-1}(P<0.05)$. The total titrated dose of intrathecal morphine, total dose of im rescue morphine and frequency of intrathecal morphine titration during phase $\mathrm{M}+\mathrm{K}$ was less than in phase $\mathrm{M}(P$ $<0.05$ ) (Table II).

Pain intensity and frequency on the day before intrathecal morphine administration and on the last days of phase $M$ and $M+K$ are shown in Figure. 1. Pain intensity (numeric rating scale) and frequency (four point verbal ordinal scale) on the day before intrathecal administration were $7.95 \pm 0.25$ and $2.45 \pm 0.17$, respectively, and these decreased to $2.20 \pm 0.17(P<$ $0.05)$ and $0.35 \pm 0.11(P<0.05)$, respectively, on the last day of phase $\mathrm{M}$ and to $1.95 \pm 0.20(P<0.05)$ and
TABLE II Intrathecal and rescue morphine requirements, and frequency of intrathecal morphine titration in Phase $M$ and Phase $M+K$

\begin{tabular}{lcc}
\hline & Phase $M$ & Phase $M+K$ \\
\hline $\begin{array}{l}\text { Effective dose of intrathecal } \\
\text { morphine (mg) }\end{array}$ & $0.38 \pm 0.04$ & $0.17 \pm 0.02^{*}$ \\
$\begin{array}{l}\text { Total dose of intrathecal } \\
\text { morphine during treatment }(\mathrm{mg})\end{array}$ & $1.32 \pm 0.19$ & $0.38 \pm 0.08^{*}$ \\
$\begin{array}{l}\text { Total dose of rescue morphine } \\
\text { during treatment }(\mathrm{mg})\end{array}$ & $33.25 \pm 7.40$ & $9.00 \pm 3.58^{*}$ \\
$\begin{array}{c}\text { Frequency of intrathecal } \\
\text { morphine titration }\end{array}$ & $9.10 \pm 0.51$ & $5.00 \pm 0.40^{*}$ \\
\hline
\end{tabular}

Value are mean $\pm \mathrm{SEM}, n=20$.

Phase $M$, intrathecal morphine only; phase $M+K$, co-administered ketamine $1 \mathrm{mg}$ with morphine.

$* P<0.05$ vs Phase $\mathrm{M}$.

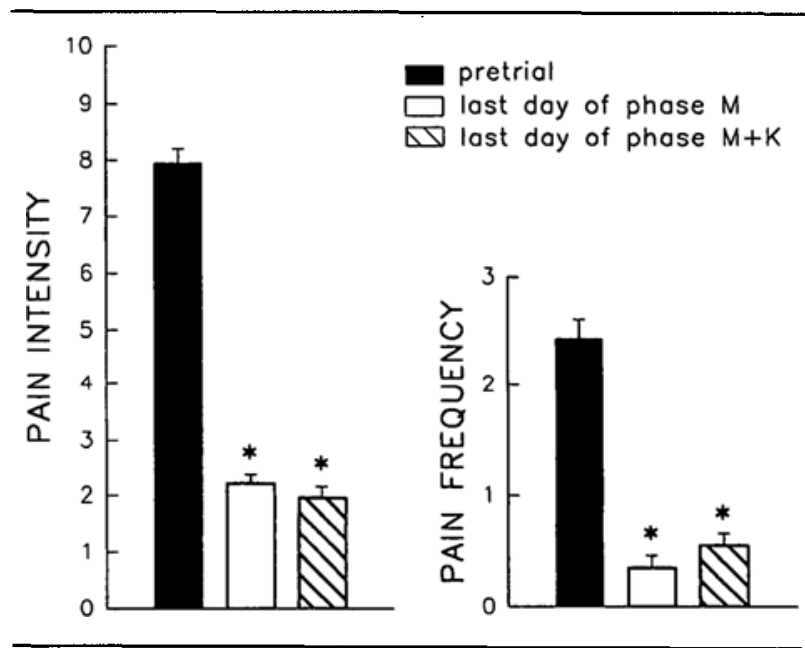

FIGURE 1 Pain intensity (numeric rating scale) and frequency (four point verbal ordinal scale) on the day before intrathecal administration and on the last day of the two phases. Value are mean $\pm \operatorname{SEM}, n=20$. Phase $M$, intrathecal morphine only; phase $M+K$, co-administrated ketamine $1 \mathrm{mg}$ with morphine. ${ }^{*} P<0.05$ vs before intrathecal administration.

$0.55 \pm 0.11(P<0.05)$, respectively, on the last day of phase $\mathrm{M}+\mathrm{K}$.

Most of the patients had life interference and sleep deprivation before intrathecal administration, with scales (numeric rating scale) averaging $7.60 \pm 0.29$ and $7.45 \pm 0.29$, respectively. These improved after intrathecal drug administration to $2.25 \pm 0.25(P<0.05)$ and $2.00 \pm 0.63(P<0.05)$ on the last day of phase $\mathrm{M}, 2.05$ $\pm 0.25(P<0.05)$ and $1.65 \pm 0.48(P<0.05)$ on the last day of phase $M+K$ (Figure. 2).

Side effects including pruritus, constipation, urinary retention, difficulty of urination, nausea, vomiting and hallucination, were not serious and respiratory depression did not occur (Table III). 


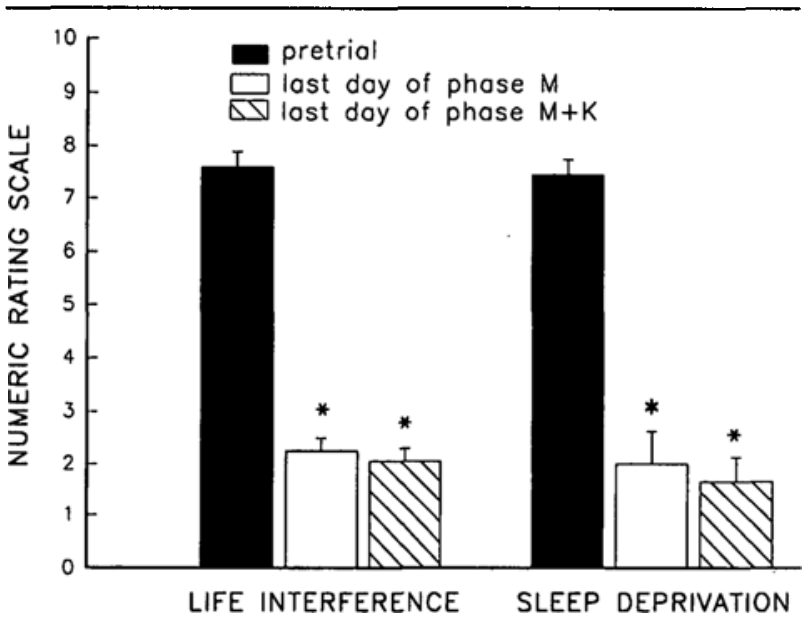

FIGURE 2 Life interference and sleep deprivation on the day before intrathecal administration and on the last day of the two phases. Value are mean $\pm \mathrm{SEM}, n=20$. Phase $\mathrm{M}$, intrathecal morphine only; phase $\mathrm{M}+\mathrm{K}$, co-administrated ketamine $1 \mathrm{mg}$ with morphine. $* P<0.05$ vs before intrathecal administration

TABLE III Frequency and incidence of side effects $(n=20)$.

\begin{tabular}{llll}
\hline Side effects & Pretrial & Phase I & Phase II \\
\hline Pruritus & $0(0 \%)$ & $5(25 \%)$ & $3(15 \%)$ \\
Constipation & $4(20 \%)$ & $5(25 \%)$ & $4(20 \%)$ \\
Urinary retention & $2(10 \%)$ & $4(20 \%)$ & $2(10 \%)$ \\
Difficult urination & $2(10 \%)$ & $7(35 \%)$ & $7(35 \%)$ \\
Nausea & $6(30 \%)$ & $8(40 \%)$ & $6(30 \%)$ \\
Vomiting & $5(25 \%)$ & $6(30 \%)$ & $4(20 \%)$ \\
Hallucinations & $0(0 \%)$ & $1(5 \%)$ & $0(0 \%)$ \\
Respiratory depression & $0(0 \%)$ & $0(0 \%)$ & $0(0 \%)$ \\
\hline
\end{tabular}

Five patients experienced pruritus during phase $M$, and three during phase $M+K$. Four patients were constipated before intrathecal administration and during phase $\mathrm{M}+\mathrm{K}$, and one additional patient experienced constipation during phase $\mathrm{M}$. Difficulty in voiding was a major side effect. Two patients needed bladder catheterization before intrathecal drug administration, and a further two patients developed urinary retention during phase $M$. Five patients experienced difficulty of urination after intrathecal drug administration during phases $M$ and $\mathrm{M}+\mathrm{K}$. Six patients experienced nausea before intrathecal drug administration and during phase $M$ and $M+K$, and two additional patients experienced nausea only during phase M. Five patients experienced vomiting before intrathecal drug treatment; one additional patient experienced it during phase $M$, but only four patients vomited during phase $M+K$. One patient had hallucinations during phase $M$, but these improved during phase $M+K$. The frequency of these side effects did not show differences between phase $M$ and phase $M+K(P>0.05)$.

\section{Discussion}

The present study showed pain intensity, frequency, life interference and sleep deprivation were all decreased on the last days of phases $M$ and $M+K$. Intrathecal morphine alone or the co-administration of morphine with ketamine intrathecally can control cancer pain and improve the life and sleep of patients. The dose of intrathecal morphine on the last day of phase $\mathrm{M}+\mathrm{K}$ was less than that on the last day of phase $M$, suggesting that co-administration of morphine with small dose of ketamine $(1 \mathrm{mg})$ intrathecally reduces the intrathecal dose of morphine required for the control of cancer pain, and is as effective as intrathecal morphine alone. Recently, animal experiments have shown that systemic administration of NMDA receptor antagonists attenuates non-associative opioid tolerance. ${ }^{11-13}$ Gustein et al. ${ }^{14}$ demonstrated that non-competitive NMDA receptor antagonist, MK-801, prevents the development of morphine tolerance at spinal sites of rats, Furthermore, we demonstrated that co-administration of MK-801 with morphine intrathecally inhibits the development of morphine tolerance in rats. ${ }^{15}$ Ketamine, a non-competitive NMDA antagonist, interacts with morphine and potentiates the action of morphine in rats. ${ }^{8,9}$ Trujillo et al. ${ }^{13}$ further demonstrated that ketamine inhibits opioid tolerance in rats. In human investigations, ketamine has been used for post-operative pain relief. Islas et al. ${ }^{3}$ found that epidural ketamine produced postoperative pain relief without opioid-induced side effects. Laird et al. ${ }^{16}$ and Clark et al. ${ }^{17}$ reported that ketamine might reverse morphine tolerance in two patients with severe cancer pain. Recently, we demonstrated that epidural ketamine potentiates the analgesic effect of morphine in patients undergoing total knee replacement. ${ }^{18}$ The present findings support results from studies in animals and humans, indicating that there is an interaction between ketamine and morphine: ketamine potentiates the analgesic action of morphine. ${ }^{8,9,13,16-18}$

From the beginning of intrathecal morphine titration, the total intrathecal titrated dose, total im rescue dose and intrathecal titrated frequency of morphine during phase $M+K$ to achieve acceptable pain relief was less than in phase $M$, suggesting that the concomitant use of intrathecal ketamine and morphine is more convenient for morphine's titration and adjustment than intrathecal morphine alone.

Side effects in this study included pruritus, constipation, urinary retention, difficult urination, nausea, vomiting and hallucination. Pruritus was the most common adverse effect of intrathecal drugs but its mechanism is still unknown. ${ }^{7}$ Difficulty in urination was also common and occurred only in men. Urinary retention was the most troublesome complication. ${ }^{7,19}$ It did not occur fre- 
quently, but only in two additional patients during phase M. Nausea, vomiting, and constipation were seen but most of these symptoms existed before intrathecal drug treatment started. One patient developed hallucinations during phase $\mathbf{M}$, and he had required a larger dose of morphine to relieve his pain. Hallucinations disappeared when the morphine dose was reduced during phase $M+K$. There were no serious side effects in this study such as life-threatening respiratory depression, ${ }^{20,21}$ perhaps because the dose of intrathecal morphine was adjusted by titration and overdose was avoided. Although the incidence of some side effects numerically was lower in the $\mathrm{M}+\mathrm{K}$ group than in group $\mathrm{M}$, the difference was not statistically significant, probably because of the small number of patients and brief trial period.

In conclusion, co-administration of intrathecal morphine with a small dose of ketamine $(1 \mathrm{mg})$ reduces the intrathecal dose of morphine required to control cancer mediated pain and is as effective as intrathecal morphine alone. The concomitant use of intrathecal morphine and ketamine appeared to enable easier adjustment of the dose of intrathecal morphine than intrathecal morphine alone. There were no serious side effects. Thus, the concomitant use of intrathecal morphine and ketamine is an effective and safe method of cancer pain control.

\section{Acknowledgements}

The authors are grateful to National Science Council (NSC), Taipei, Taiwan, ROC for their grant support.

\section{References}

1 Kawana $Y$, Sato H, Shimada $H$, et al. Epidural ketamine for postoperative pain relief after gynecologic operations. A double-blind study and comparison with epidural morphine. Anesth Analg 1987; 66: 735-8.

2 Islas J-A, Astorga J, Laredo $M$. Epidural ketamine for control of postoperative pain. Anesth Analg 1985; 64: 1161-2.

3 Bion JF. Intrathecal ketamine for war surgery. A preliminary study under field conditions. Anaesthesia 1984; 39 : 1023-8.

4 Brock-Utne JG, Mankowitz E, Kallichurum S, Downing $J W$. Effects of intrathecal saline and ketamine with and without preservative on the spinal nerve roots of monkeys. S Afr Med J 1982; 61: 360-1.

5 Brock-Utne JG, Kallichurum S, Mankowitz E, Maharaj RJ, Downing $J W$. Intrathecal ketamine with preservative histological effects on spinal nerve roots of baboons. S Afr Med J 1982; 61: 440-1.

6 Cousins MJ, Mather LE. Intrathecal and epidural administration of opioids. Anesthesiology 1984; 61: 276-310.

7 Payne R. Role of epidural and intrathecal narcotics and peptides in the management of cancer pain. Med Clin North Am 1987; 71: 313-27.

8 Hance AJ, Winters WD, Quam DD, Benthuysen $J L$, Cadd $G G$. Catalepsy induced by combinations of ketamine and morphine: potentiation, antagonism, tolerance and crosstolerance in the rat. Neuropharmacology $1989 ; 28$ : 109-16.

9 Winters WD, Hance AJ, Cadd GG, Quam DD, Benthuysen $J L$. Ketamine- and morphine-induced analgesia and catalepsy. 1. Tolerance, cross-tolerance, potentiation, residual morphine levels and naloxone action in the rat. J Pharmacol Exp Ther 1988; 244: 51-7.

10 Cousins MJ, Cherry DA, Gourlay GK. Acute and chronic pain: use of spinal opioids, In: Cousins MJ, Bridenbaugh PO (Eds.). Neural Blockade in Clinical Anesthesia and Management of Pain, 2nd ed. Philadelphia: J. B. Lippincott Company, 1988: 955-1026.

11 Ben-Eliyahu S, Marek P, Vaccarino AL, Mogil JS, Sternberg WF, Liebeskind JC. The NMDA receptor antagonist MK-801 prevents long-lasting non-associative morphine tolerance in the rats. Brain Res. 1992; 575: 304-8.

12 Trujillo $K A$, Akil $H$. Inhibition of morphine tolerance and dependence by the NMDA receptor antagonist MK- 801 . Science 1991; 251: 85-7.

13 Trujillo KA, Akil $H$. Inhibition of opiate tolerance by non-competitive $N$-methyl-D-aspartate receptor antagonists. Brain Res. 1994; 633: 178-88.

14 Gutstein HB, Trujillo KA. MK-801 inhibits the development of morphine tolerance at spinal sites. Brain Res 1993; 626: 332-4.

15 Wong C-S, Cherng C-H, Luk H-N, Ho S-T, Tung C-S. Effects of NMDA receptor antagonists on inhibition of morphine tolerance in rats: biding of $\mu$-opioid receptors. Eur J Pharmacol, in press.

16 Laird D, Lovel T. Paradoxical pain (Letter). Lancet; 341 241.

17 Clark JL, Kalan GE. Effective treatment of severe cancer pain of the head using low-dose ketamine in an opioid-tolerant patient. J Pain Symptom Manage 1995; 10: 310-4.

18 Wong C-S, Liaw W-J, Tung C-S, Su Y-F, Ho S-T. Ketamine potentiates analgesic effect of morphine in postoperative epidural pain control. Reg Anesth, in press.

19 Bromage PR, Camporesi EM, Durant PAC, Nielsen CH. Nonrespiratory side effects of epidural morphine. Anesth Analg 1982; 61: 490-5.

20 Davies GK, Tolhurst-Cleaver CL, James TL. Respiratory depression after intrathecal narcotics. Anaesthesia 1980; 35: 1080-3.

21 Glynn CJ, Mather LE, Cousins MJ, Wilson PR, Graham $J R$. Spinal narcotics and respiratory depression (Letter). Lancet $1979 ; 1$ : 356-7. 